\title{
ANALISIS WAKTU ARAH PLANAR DAN SUDUT PERMUKAAN BIDANG KERJA TERHADAP KEKASARAN PERMUKAAN MATERIAL FC25 HASIL PEMESINAN PADA MESIN CNC MILLING MENGGUNAKAN BALLNOSE ENDMILL
}

\author{
Sunarno $^{1}$, Sri Mulyo Bondan Respati ${ }^{2 *}$, Rony Wijanarko ${ }^{2}$ \\ ${ }^{1}$ PT. Tri Sinar Purnama Desa Kedung Pani, Kelurahan Wates, \\ Kecamatan Ngaliyan, Semarang 50188 \\ ${ }^{2}$ Jurusan Teknik Mesin, Fakultas Teknik, Universitas Wahid Hasyim \\ Jl. Menoreh Tengah X/22, Sampangan, Semarang 50236. \\ "Email: srimulyobondanrespati@unwahas.ac.id
}

\begin{abstract}
Abstrak
Lama waktu saat proses produksi merupakan faktor yang sangat penting dalam suatu perusahaan untuk memprediksi jumlah produksi yang dihasilkan dalam periode tertentu. Nilai sebuah produk salah satunya adalah kualitas permukaan. Proses finishing mempunyai kualitas nilai kekasaran permukaaan yang berbeda dengan metode proses yang berbeda pula. Penelitian ini bertujuan untuk mengetahui dan menganalisa waktu dan kekasaran permukaan material FC25 hasil pemesinan CNC milling. Metode yang digunakan dengan memvariasikan arah planar $45^{\circ}, 90^{\circ}$, berputar konstan sumbu $Z$ dan variasi sudut bidang kerja $0^{\circ}, 30^{\circ}, 45^{\circ}, 60^{\circ}$. Increment 0,3 mm spindle $7962 \mathrm{rpm}$, feeding $1115 \mathrm{~mm} /$ menit dan feed depth 0,4 mm. Pengujian waktu proses planar menggunakan kontrol pengendali siemens sinumerik $828 \mathrm{D}$ dan pengujian kekasaran menggunakan TR 100 Surface Roughness Tester. Dihasilkan perbedaan waktu proses dengan simulasi software sebesar 112 detik (waktu pemesinan meningkat 4.9\%). Waktu paling lama 242 detik pada sudut bidang kerja $0^{\circ}$ dengan arah planar berputar konstan sumbu $Z$ dan waktu paling cepat 119 detik pada sudut bidang kerja $30^{\circ}$ dengan arah planar berputar konstan sumbu Z. Nilai kekasaran paling rendah 0,74 $\mu$ m pada sudut bidang kerja $0^{\circ}$ dengan arah planar $90^{\circ}$ dan nilai kekasaran paling tinggi 3,21 $\mu$ m pada sudut bidang kerja $60^{\circ}$ dengan arah planar $90^{\circ}$. Arah planar $90^{\circ}$ dan $45^{\circ}$ semakin besar sudut bidang kerja maka semakin menurun waktu yang dihasilkan tetapi semakin besar nilai kekasarannya, berbanding terbalik dengan planar berputar konstan sumbu Z, semakin besar sudut bidang kerja maka semakin meningkat waktu yang dihasilkan tetapi nilai kekasarannya menurun.
\end{abstract}

Kata kunci: arah planar, ballnose endmill, CNC milling, FC25, kekasaran permukaan.

\section{PENDAHULUAN}

Proses produksi merupakan suatu proses untuk menghasilkan barang dan jasa. Proses produksi melibatkan beberapa faktor antara lain waktu, tenaga, SDM, bahan baku, mesin serta alur produksi. Lama waktu proses pemesinan merupakan faktor yang sangat penting dalam suatu perusahaan untuk memprediksi jumlah produksi yang akan dihasilkan dalam periode tertentu.

Perkembangan teknologi sangat pesat menuntut persaingan semakin ketat. Banyak jenis-jenis material telah ditemukan untuk memenuhi kebutuhan industri baik berupa logam maupun non logam. Mesin-mesin banyak dibuat untuk mempermudah proses produksi manufaktur, terus berkembang seiring dengan kemampuan sumber daya manusia. Mesin yang dulunya dioperasikan secara manual, kini telah berkembang menjadi mesin otomatis yang dijalankan dengan menggunakan program komputer (Yudhyadi dkk, 2006). Sebuah program dengan menggunakan bahasa numerik yang biasa disebut program CNC (Computer Numerically Controlled). Mesin dengan fasilitas program CNC mempunyai kemampuan yang tidak dimiliki mesin konvensional. Tool dapat berpindah digerakkan secara otomatis menurut kebutuhan yang diinginkan. Berbagai bentuk yang rumit dengan ketelitian dan kepresisian yang tinggi menjadikan kualiatas produk yang dihasilkan mempunyai kualitas lebih baik. Proses simulasi pergerakan tool dapat dimonitor untuk meminimalisasi human error yang berimbas pada keselamatan baik produk, mesin, ataupun operator.

Efisiensi waktu juga menjadi lebih baik karena dapat diketahui waktu yang dibutuhkan pada saat proses simulasi program. Kualitas sebuah produk yang dihasilkan berhubungan dengan kualitas harga jual produk. Produk berkualitas baik tentunya dibuat melalui proses yang baik menggunakan mesin-mesin berkualitas baik pula. Bermacam-macam mesin 
produksi seperti mesin bubut (turning), mesin frais (milling), mesin sekrap, mesin bor (drilling), gerinda (grinding), dan lain sebagainya digunakan pada proses produksi pembuatan komponen pemesinan.

Berbagai penelitian dan analisa pada banyak disiplin ilmu telah dikembangkan baik pada instansi pendidikan maupun industri. Wahid (2016) melakukan analisa arah pemakanan dan sudut Permukaan bidang kerja terhadap Kekasaran permukaan material S45C pada mesin frais CNC menggunakan ballnose endmill. Penggunaan mesin CNC sebagai mesin perkakas dalam proses pemesinan modern semakin banyak dijumpai dalam industri manufaktur, CNC milling dalam hal ini memiliki fungsi untuk mengerjakan suatu komponen secara efisien, hemat waktu, dan hemat biaya, Maka berdasar penelitian Wahid (2016) akan dikembangkan penelitian tentang optimasi waktu arah planar dan sudut permukaan bidang kerja terhadap kekasaran permukaan material FC25 Pada mesin CNC milling menggunakan ballnose endmill

FC25 adalah besi cor yang salah satunya digunakan untuk membuat corebox yang berfungsi sebagai alat pembuat inti dalam perusahaan pengecoran. Proses akhir (finishing) dalam proses pembuatan corebox tersebut menggunakan alat potong (cutting tool) ballnose endmill. Dengan alat potong ballnose endmill tersebut yang nantinya akan mengakhiri dalam sebuah proses pemesinan.

Proses planar yang dilakukan pada mesin CNC milling adalah proses penyayatan terakhir (finishing) benda kerja menggunakan alat potong yang berputar. Beberapa parameter yang bisa mempengaruhi proses pemesinan adalah cutting speed, feedrate, dan depth of cut (kedalaman pemakanan). Pemilihan parameter pemotongan yang tepat dalam proses pemesinan adalah hal yang sangat penting untuk meraih kualitas produk yang baik serta proses yang ekonomis dan produktif (Draganescu dkk, 2001).

Penelitian ini mempunyai tujuan untuk analisa waktu proses planar (finishing) pada mesin $C N C$ milling menggunakan alat potong ballnose endmill dan mengetahui seberapa besar pengaruh sudut permukaan bidang kerja terhadap nilai kekasaran permukaan hasil pemesinan material $F C 25$ dengan memberikan variasi arah planar dan sudut permukaan bidang kerja.

\section{METODE}

Diagram alir desain percobaan seperti terlihat pada Gambar 1.

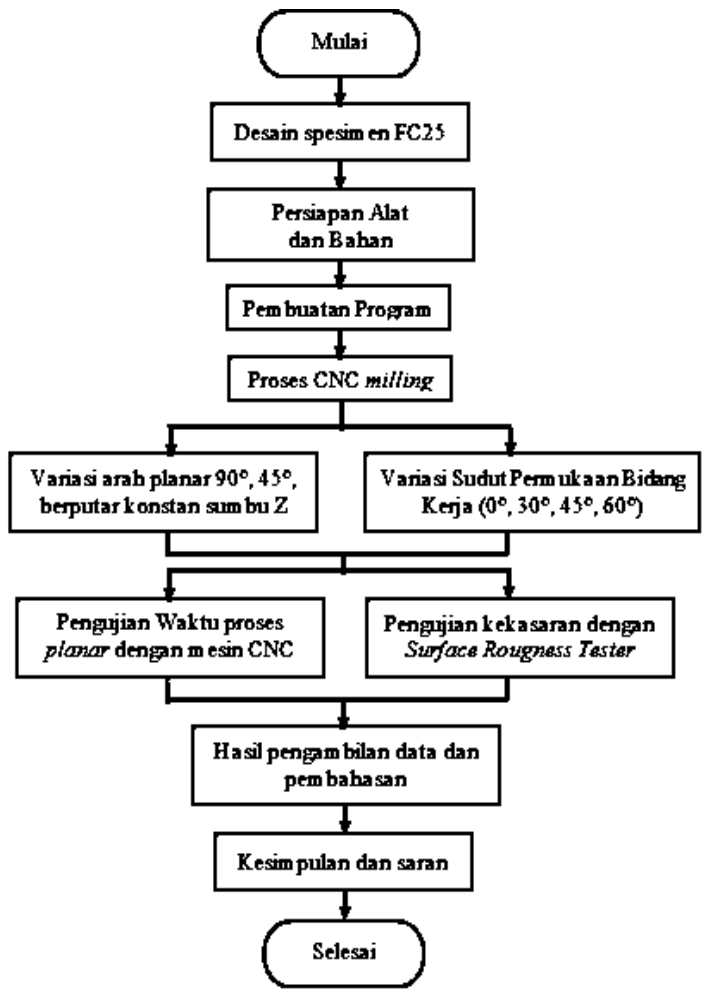

Gambar 1. Diagram alir desain percobaan

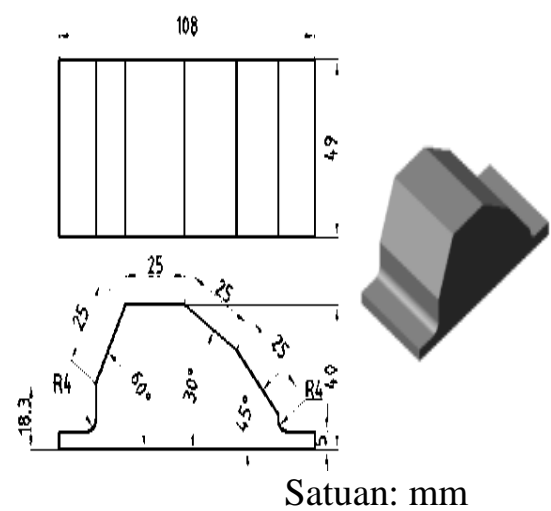

\section{Gambar 2. Desain Spesimen}

Proses pembentukan spesimen pada penelitian ini menggunakan mesin CNC milling GXV 1000. Penelitian percobaan menggunakan kecepatan putar (rpm), feeding, dan diameter alat potong sesuai spesifikasi cutting tool Guhring ballnose solid carbide. Penelitian ini dilakukan dengan tahapan-tahapan sebagai berikut:

1. Perancangan desain spesimen FC 25 seperti terlihat pada Gambar 2.

2. Persiapan alat dan bahan 
Spesimen yang akan dibuat berjenis besi cor $F C 25$. Alat yang digunakan dalam penelitian antara lain:

- $\quad$ Mesin CNC milling GXV 1000

- Endmill guhring solid carbide diameter 12 mm (Guhring, 2016)

- $\quad$ Guhring ballnose solid carbide diameter 8 mm (Guhring, 2016)

- Parallel pad

- Tool holder BT 40

- Collet Type ER 32

- Z setter

- Wrench Collets ER

- Jangka sorong 12 inchi

- Panel kontrol sinumeric 828D

- TR100 Surface Roughness Tester,

3. Pembuatan program

Pembuatan program menggunakan bantuan aplikasi CAD/CAM. Jenis CAD/CAM yang digunakan adalah SurfCam Velocity 3.0 B357 (Gambar II.3). Pada penelitian ini menggunakan toolpath 3 axis $\mathrm{Z}$ rough untuk rough milling dan planar (finish milling) searah $90^{\circ}, 45^{\circ}$ dan pocket $Z$ finish (Berputar konstan sumbu Z) . Kondisi proses pemotongan dapat dilihat pada Tabel 1.

Tabel 1. Kondisi pemotongan(cutting condition) proses milling

\begin{tabular}{|l|c|c|c|c|}
\hline \multirow{4}{*}{ Parameter } & Rough milling & \multicolumn{3}{|c|}{ Planar (finish milling) parameter } \\
\cline { 2 - 5 } & $\begin{array}{c}\text { Adaptive } \\
\text { clearing }\end{array}$ & Arah $90^{\circ}$ & Arah $90^{\circ}$ & $\begin{array}{c}\text { Bergutar } \\
\text { Konstan } \\
\text { sumbu Z }\end{array}$ \\
\hline Tooipath parameter & \multicolumn{5}{|c|}{} \\
\hline Tool Type & Endmill & Ballnose & Ballhose & Ballnose \\
\hline Tool Diameter(mm) & 12 & 8 & 8 & 8 \\
\hline Flute & 4 & 2 & 2 & 2 \\
\hline Tool Manerial & Carbide & Carbide & Carbide & Carbide \\
\hline Spindel Speed (mm/mm) & 3450 & 7962 & 7962 & 7962 \\
\hline Feed Rate (mm/mmt) & 497 & 1115 & 1115 & 1115 \\
\hline Plunge Rate (mm/mm) & 497 & 429 & 429 & 429 \\
\hline Step tope & Climp & Increment & Increment & Increment \\
\hline Z Step Size & 0,4 & - & - & - \\
\hline Increment & - & 0,3 & 0,3 & 0,3 \\
\hline Stock To Leave & 0.4 & 0 & 0 & 0 \\
\hline Sufface Toleramce & 0,25 & 0,025 & 0,025 & 0,025 \\
\hline
\end{tabular}

\section{Proses pemesinan $C N C$ milling}

- Variasi arah planar (arah pemakanan)

Arah planar merupakan arah bergeraknya alat potong pada saat proses finish milling. Arah pemakanan pada penelitian ini dibatasi 3 arah pemakanan yaitu arah pemakanan searah $90^{\circ}$, $45^{\circ}$, dan berputar konstan sumbu Z. arah planar searah $90^{\circ}$ dan $45^{\circ}$ yang dimaksud adalah sudut $90^{\circ}$ dan $45^{\circ}$ terhadap sumbu $\mathrm{X}$ pada bidang XY. Jarak pergeseran pada arah ini adalah konstan, sedangkan arah pemakanan berputar konstan sumbu $\mathrm{Z}$ jarak pergeseran alat potong bernilai konstan pada sumbu $\mathrm{Z}$ terhadap bidang $\mathrm{XZ}$, seperti terlihat pada Gambar 4.

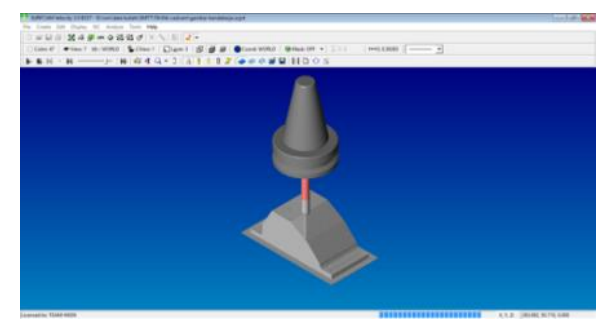

\section{Gambar 3. Tampilan aplikasi CAD/CAM SurfCam Velocity 3.0 B357}

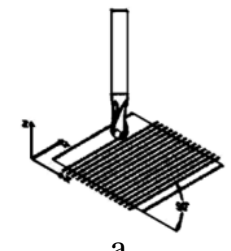

a

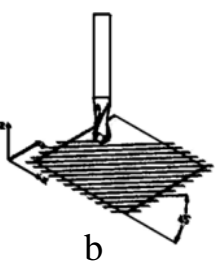

b

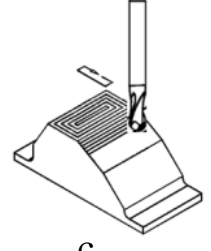

Gambar 4. Arah pemakanan (a) searah $90^{\circ}$ (b) searah $45^{\circ}$ (c) Berputar konstan sumbu Z

- Variasi sudut permukaan bidang kerja Sudut permukaan bidang kerja yang dimaksud adalah sudut pada permukaan bidang $\mathrm{X}, \mathrm{Z}$. Besar sudut diukur berdasarkan sumbu X (lihat Gambar 5.).

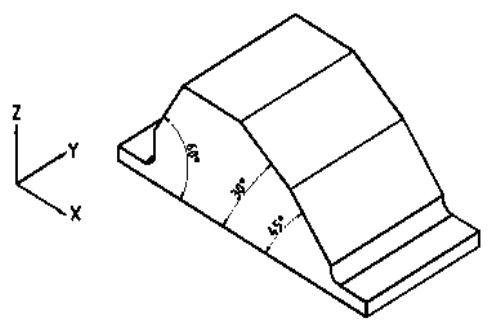

\section{Gambar II.5 Sudut permukaan bidang kerja}

5. Pengukuran hasil penelitian

- Pengukuran waktu proses planar (finishing)

Pengukuran waktu proses planar dilakukan menggunakan panel kontrol sinumeric 828D pada mesin CNC milling GXV 1000 pada saat proses planar berlangsung. Lama waktu proses berdasarkan saat program mulai dijalankan sampai dengan selesai. Proses planar terdiri dari 12 bidang, setiap bidang dilakukan pengukuran waktu dan di hitung pada saat 
spindel mulai berputar sampai spindel tersebut berhenti atau selesai proses.

- Pengukuran kekasaran permukaan.

Setelah spesimen selesai dibentuk selanjutnya dilakukan proses pengukuran kekasaran permukaan. Pengukuran dilakukan dengan menggunakan TR 100 Surface Roughness Tester untuk setiap bidang datar masing-masing 6 buah pengukuran. Peta pengukuran terhadap spesimen seperti pada Gambar 6.

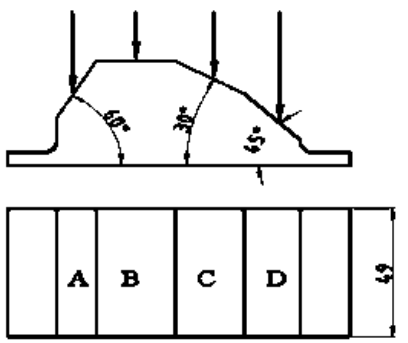

Satuan: mm

Gambar 6. Peta pengukuran kekasaran

Keterangan :

$\mathrm{A}=$ Sudut permukaan bidang kerja $60^{\circ}$

$\mathrm{B}=$ Sudut permukaan bidang kerja $0^{\circ}$

$\mathrm{C}=$ Sudut permukaan bidang kerja $30^{\circ}$

$\mathrm{D}=$ Sudut permukaan bidang kerja 45

\section{HASIL DAN PEMBAHASAN}

Hasil Pengujian waktu proses planar. Tabel 2.

Hasil waktu proses planar terlihat pada

Tabel 2. Hasil waktu proses variasi planar terhadap variasi sudut permukaan bidang kerja

\begin{tabular}{|l|c|c|c|c|c|}
\hline \multirow{2}{*}{ Variasi arah Planar } & \multicolumn{4}{|c|}{$\begin{array}{c}\text { Waktu proses planar pada variasi } \\
\text { sudut benda kerja (detik) }\end{array}$} & \multirow{2}{*}{$\begin{array}{c}\text { Total } \\
\text { waktu }\end{array}$} \\
\cline { 2 - 5 } & $0^{\circ}$ & $30^{\circ}$ & $45^{\circ}$ & $60^{\circ}$ & (detik) \\
\hline Searah90 $90^{\circ}$ & 232 & 202 & 165 & 120 & 719 \\
\hline Searah45 $45^{\circ}$ & 236 & 221 & 206 & 190 & 853 \\
\hline Berputarkonstan sumbuZ & 243 & 119 & 167 & 207 & 736 \\
\hline Total & \multicolumn{7}{|l}{} & 2308 \\
\hline
\end{tabular}

Akan dibahas waktu yang dibutuhkan dalam simulasi CAM. Fungsi simulasi untuk memperkirakan lama waktu yang dibutuhkan dan menampilkan proses simulasi manufaktur apakah sudah sesuai atau belum rancangan yang dibuat sebelum pengerjaan permesinan dilakukan. Hasil simulasi waktu proses planar menggunakan software Surf CAM seperti terlihat pada Tabel 3 .

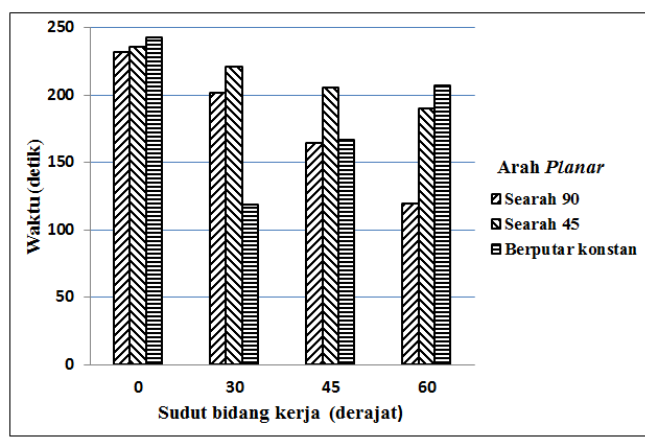

Gambar 7. Diagram waktu proses variasi planar terhadap variasi sudut bidang kerja

Tabel 3. Hasil simulasi waktu proses variasi arah planar terhadap variasi sudut benda kerja menggunakan software Surf CAM

\begin{tabular}{|c|c|c|c|c|c|}
\hline \multirow[t]{2}{*}{ Variasi arah Planar } & \multicolumn{4}{|c|}{$\begin{array}{l}\text { Waktu simulasi CAM proses } \\
\text { planar pada variasi sudut benda } \\
\text { kerja (detik) }\end{array}$} & \multirow[t]{2}{*}{$\begin{array}{l}\text { Total } \\
\text { waktu } \\
\text { (detik) }\end{array}$} \\
\hline & $0^{\circ}$ & $30^{\circ}$ & $45^{\circ}$ & $60^{\circ}$ & \\
\hline Searah $90^{\circ}$ & 223 & 194 & 157 & 113 & 687 \\
\hline Searah $45^{\circ}$ & 224 & 210 & 195 & 179 & 808 \\
\hline Berputarkonstan sumbu $Z$ & 232 & 112 & 160 & 197 & 701 \\
\hline \multicolumn{5}{|l|}{ Total } & 2196 \\
\hline
\end{tabular}

Diagram simulasi waktu proses menggunakan software SurfCAM seperti terlihat pada Gambar 8.

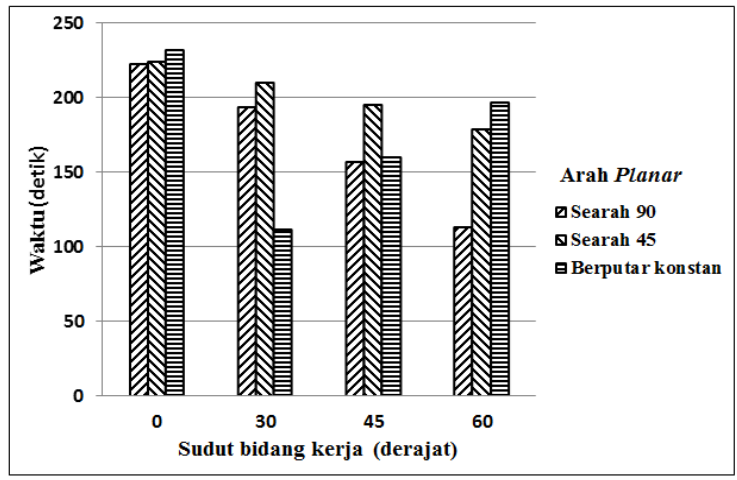

Gambar 8. Diagram simulasi waktu proses menggunakan software SurfCAM

Perbandingan waktu total proses mesin CNC dan simulasi seperti terlihat pada tabel 4. Diagram Waktu total proses mesin CNC dan simulasi CAM seperti pada Gambar 9.

Tabel 4. Waktu total proses mesin CNC dan simulasi CAM 


\begin{tabular}{|l|c|c|c|}
\hline \multirow{3}{*}{ Variasi arah Planar } & \multicolumn{2}{|c|}{$\begin{array}{c}\text { Waktu total proses mesin CNC } \\
\text { dan simulasi CAM terhadap } \\
\text { variasi sudut bidang kerja }\end{array}$} & \multirow{2}{*}{$\%$} \\
\cline { 2 - 3 } & Mesin CNC & CAM & \\
\hline Searah 90 & 719 & 687 & 4.5 \\
\hline Searah 45 & 853 & 808 & 5.3 \\
\hline Berputar konstan sumbu Z & 736 & 701 & 4.8 \\
\hline Total & 2308 & 2196 & 4.9 \\
\hline
\end{tabular}

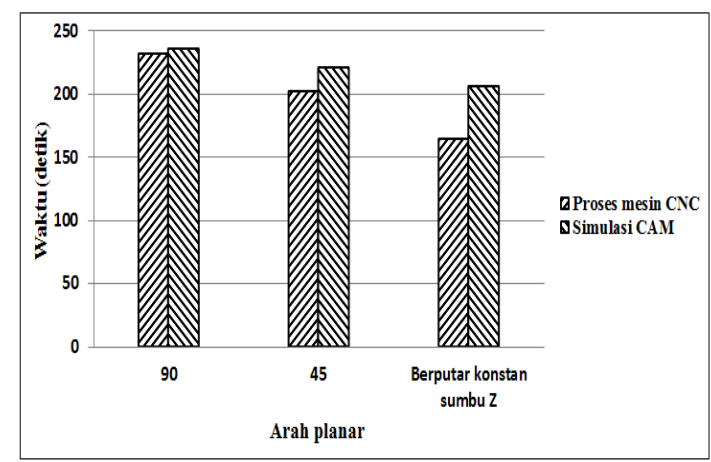

\section{Gambar 9. Diagram waktu total proses mesin CNC dan simulasi CAM}

Proses planar pada mesin CNC waktu yang dibutuhkan paling lama adalah 242 detik pada sudut bidang kerja $0^{\circ}$ dengan variasi arah planar berputar konstan sumbu $\mathrm{Z}$ dan waktu paling cepat adalah 119 detik pada sudut bidang kerja $30^{\circ}$ dengan variasi arah planar berputar konstan sumbu Z.

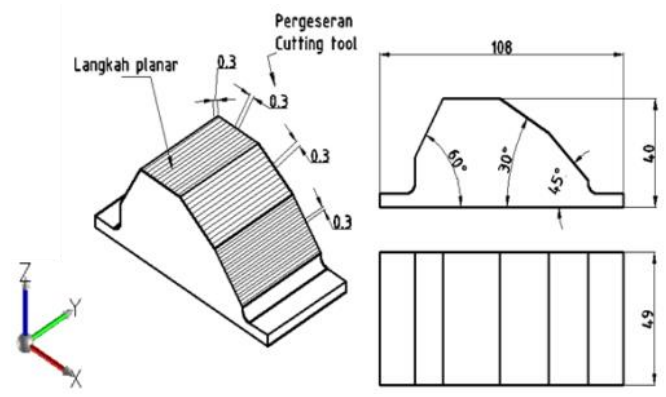

Satuan: mm

\section{Gambar 10. Pergeseran cutting tool dan langkah planar $\mathbf{9 0}^{\circ}$}

Rata-rata waktu yang dihasilkan proses planar pada mesin CNC adalah 2308 detikdan rata-rata waktu yang dihasilkan pada saat estimasi software Surf CAM adalah 2196 detik sehingga terjadi perbedaan waktu sebesar 112 detik atau proses planar pada mesin CNC mengalami peningkatan waktu sebesar $4.9 \%$ dari estimasi software SurfCAM.

Proses arah planar $90^{\circ}$ semakin besar variasi sudut bidang kerja maka semakin menurun waktu yang dihasilkan disebabkan pergeseran cutting tool arah sumbu X konstan sebesar $0,3 \mathrm{~mm}$ sehingga semakin besar sudut benda kerja jumlah langkah proses planar semakin berkurang sehingga waktu yang diperlukan semakin menurun. Gambar pergeseran cutting tool dan langkah proses arah planar $90^{\circ}$ seperti pada Gambar 10.

Arah planar $45^{\circ}$ semakin besar variasi sudut bidang kerja maka semakin menurun waktu yang dihasilkan disebabkan pergeseran cutting tool arah sumbu X konstan sebesar 0,424 $\mathrm{mm}$ sehingga semakin besar sudut benda kerja jumlah langkah proses planar semakin berkurang sehingga waktu yang diperlukan semakin menurun. Gambar pergeseran cutting tool dan langkah proses arah planar $45^{\circ}$ seperti pada Gambar 11.

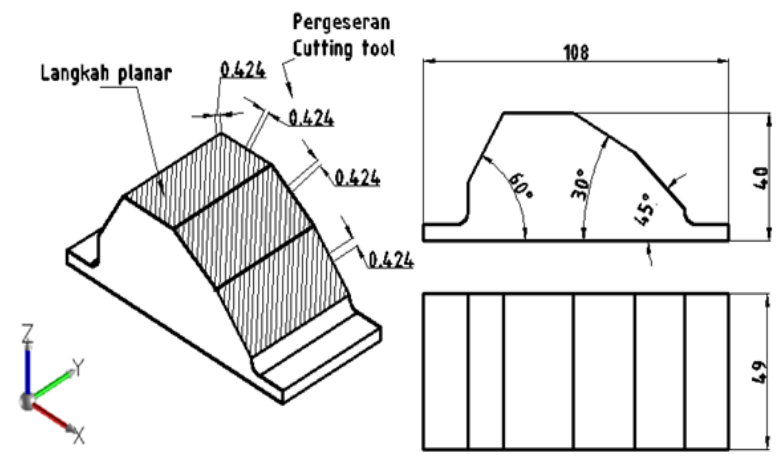

Satuan: mm

\section{Gambar 11. Pergeseran cutting tool dan langkah planar $\mathbf{4 5}^{\circ}$}

Arah planar berputar konstan sumbu $\mathrm{Z}$ semakin besar variasi sudut bidang kerja maka semakin meningkat waktu yang dihasilkan disebabkan pergeseran cutting tool arah sumbu $\mathrm{X}$ pada sudut bidang kerja $0^{\circ}$ sebesar $0,3 \mathrm{~mm}$, sudut bidang kerja $30^{\circ}$ sebesar $0,52 \mathrm{~mm}$, sudut bidang kerja $45^{\circ}$ sebesar $0,299 \mathrm{~mm}$, dan sudut bidang kerja $60^{\circ}$ sebesar $0,173 \mathrm{~mm}$ sehingga semakin besar sudut benda kerja jumlah langkah proses planar semakin bertambah sehingga waktu yang diperlukan semakin meningkat. Gambar pergeseran cutting tool dan langkah proses arah planar berputar konstan sumbu $\mathrm{Z}$ seperti pada Gambar 12. 


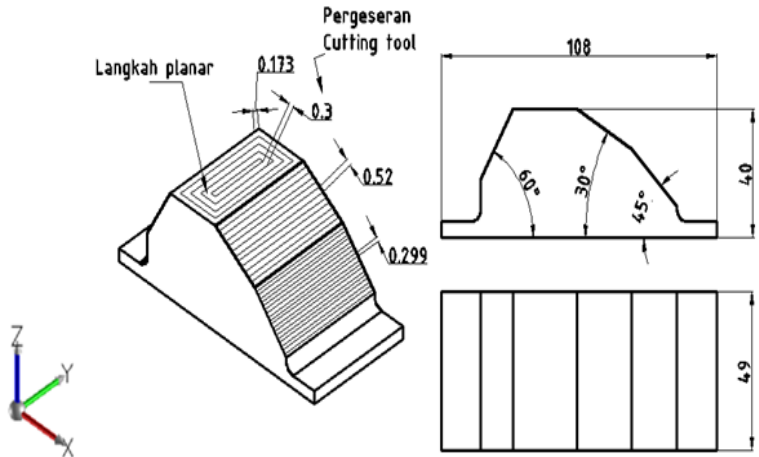

Satuan: mm

\section{Gambar 12. Pergeseran cutting tool dan langkah planar konstan sumbu $\mathrm{Z}$}

Proses variasi arah planar terhadap variasi sudut bidang kerja memiliki pergeseran cutting tool arah sumbu X yang berbeda sehingga jumlah langkah proses variasi arah planar akan berbeda pula. Pergeseran cutting tool pada sumbu $\mathrm{X}$ dan jumlah langkah proses planar terlihat pada Tabel 5.

Tabel 5. Nilai pergeseran cutting tool dan jumlah langkah proses planar seperti terlihat pada

\begin{tabular}{cccc}
\hline Arah Planar & $\begin{array}{c}\text { Sudut } \\
\text { bendakerja } \\
\text { (derajat) }\end{array}$ & $\begin{array}{c}\text { Pergeseran } \\
\text { cutting tool arah } \\
\text { sumbu X (mm) }\end{array}$ & $\begin{array}{c}\text { Jumlah } \\
\text { langkah } \\
\text { Planar }\end{array}$ \\
\hline \multirow{4}{*}{$90^{\circ}$} & 0 & 0,3 & 84 \\
& 30 & 0,3 & 73 \\
& 45 & 0,3 & 59 \\
& 60 & 0,3 & 42 \\
\hline \multirow{4}{*}{$45^{\circ}$} & 0 & 0,424 & 175 \\
& 30 & 0,424 & 167 \\
& 45 & 0,424 & 157 \\
Berputar & 60 & 0,424 & 145 \\
konstansumbu & 0 & 0,3 & 82 \\
$Z$ & 30 & 0,52 & 42 \\
& 45 & 0,301 & 59 \\
\hline
\end{tabular}

\section{Pengujian Kekasaran Permukaan.}

Hasil pengujian kekasaran yang telah dilakukan menggunakan Surface Roughness Tester TR100 diperoleh data yang diambil pada 6 titik pengujian kemudian hasil dirata-rata. Hasil rata-rata pengujian seperti terlihat pada tabel 6.
Tabel 6. Hasil nilai kekasaran rata-rata

\begin{tabular}{lcccc}
\hline \multirow{3}{*}{ Arah Planar } & \multicolumn{4}{c}{ Nilai kekasaran $\left(R_{a}\right)$ pada sudut permukaan } \\
& \multicolumn{4}{c}{ bidang kerja $(u \mathrm{~m})$} \\
\cline { 2 - 5 } & $0^{\circ}$ & $30^{\circ}$ & $45^{\circ}$ & $60^{\circ}$ \\
\hline Searah $90^{\circ}$ & 0,74 & 1,41 & 1,52 & 3,21 \\
Searah 45 & 0,76 & 1,20 & 1,26 & 1,61 \\
Berputar konstan & 1,21 & 2,55 & 1,14 & 1,13 \\
sumbu Z & & & & \\
\hline
\end{tabular}

Diagram perbandingan nilai $R_{a}$ antara variasi arah Planar terhadap variasi sudut permukaan bidang kerja terlihat pada Gambar 13.

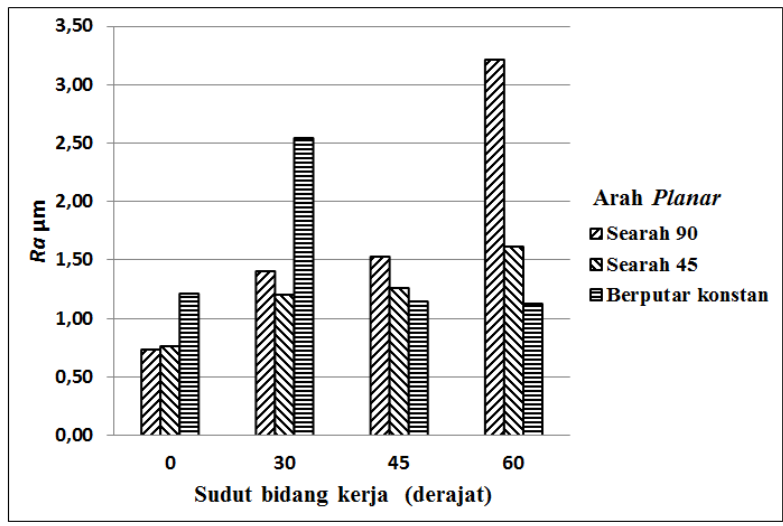

Gambar 13. Diagram perbandingan nilai $\boldsymbol{R}_{a}$ antara variasi arah Planar terhadap variasi sudut permukaan bidang kerja

Nilai $R_{a}$ pada arah planar searah $45^{\circ}$ dan $90^{\circ}$ semakin besar sudut bidang kerja maka semakin besar pula nilai $R_{a}$ yang dihasilkan. Sedangkan pada arah pemakanan konstan sumbu $\mathrm{Z}$ berbanding terbalik terhadap keduanya. Semakin besar sudut bidang kerja maka semakin kecil nilai $R_{a}$ yang dihasilkan karena terdapat perbedaan pergeseran cutting tool arah sumbu X pada setiap variasi sudut bidang kerja yang menyebabkan ketinggian profil permukaan benda kerja akan berbeda.

Hasil nilai kekasaran permukaan paling rendah adalah $0,74 \mu \mathrm{m}$ pada sudut permukaan bidang kerja $0^{\circ}$ dengan variasi arah planar $90^{\circ}$ sedangkan hasil nilai kekasaran permukaan paling tinggi adalah $3,21 \mu \mathrm{m}$ pada sudut permukaan bidang kerja $60^{\circ}$ dengan variasi arah planar $90^{\circ}$. 


\section{KESIMPULAN}

1. Waktu total yang dihasilkan pada saat proses planar di mesin CNC 2308 detik dan waktu total proses planar simulasi software SurfCAM 2196 detik sehingga terjadi perbedaan waktu 112 detik atau waktu proses planar pada mesin CNC mengalami peningkatan sebesar $4.9 \%$ dari simulasi software SurfCAM. Waktu yang dibutuhkan pada saat proses pemesinan paling lama adalah 242 detik pada sudut bidang kerja $0^{\circ}$ dengan variasi arah planar berputar konstan sumbu $\mathrm{Z}$ dan waktu yang dibutuhkan pada saat proses pemesinan paling cepat adalah 119 detik pada sudut bidang kerja $30^{\circ}$ dengan variasi arah planar berputar konstan sumbu Z. Arah planar $90^{\circ}$ dan $45^{\circ}$ semakin besar variasi sudut bidang kerja maka semakin menurun waktu yang dihasilkan, berbanding terbalik dengan arah planar berputar konstan sumbu Z, semakin besar variasi sudut benda kerja maka semakin meningkat waktu yang dihasilkan.

2. Hasil nilai kekasaran permukaan paling rendah adalah $0,74 \mu \mathrm{m}$ pada sudut permukaan bidang kerja $0^{\circ}$ dengan variasi arah planar $90^{\circ}$ sedangkan hasil nilai kekasaran permukaan paling tinggi adalah $3,21 \mu \mathrm{m}$ pada sudut permukaan bidang kerja $60^{\circ}$ dengan variasi arah planar $90^{\circ}$, nilai kekasaran permukaan arah planar $90^{\circ}$ dan $45^{\circ}$, semakin besar sudut benda kerja maka semakin besar nilai kekasaran benda kerjanya, berbanding terbalik dengan arah planar berputar konstan sumbu Z, semakin besar variasi sudut benda kerja maka semakin menurun nilai kekasarannya.

\section{DAFTAR PUSTAKA}

Draganescu F., Gheorghe M., Doicin C.V., 2003, Models of machine tool efficiency and specific consumed energy, Journal of Materials Processing Technology, Vol.141, No.1, pp. 9 - 15.

Guhring, 2016, Milling tools for the mould and die industry, Guhring, Indonesia

Wahid, A., Syafa'at, I, dan Respati, B, 2016, Analisa Arah Pemakanan Dan Sudut Permukaan Bidang Kerja Terhadap Kekasaran Permukaan Material S45C Pada Mesin Frais CNC Menggunakan Ballnose Endmil, Jurnal ilmiah Fakultas Teknik Unwahas, ISSN:0216-7395,e-
ISSN:2406-9329, Universitas Wahid Hasyim Semarang

Yudhyadi, dkk., 2016, Optimasi Parameter Permesinan Terhadap Waktu Proses Pada Pemrograman Cnc Milling Dengan Berbasis Cad/Cam, Dinamika Teknik Mesin, Volume 61 juni 2016, p. ISSN: 2088-088X, e. ISSN: 2502-1729 Universitas Mataram, Indonesia. 